UDC: $811.111^{\prime} 342.9$

D0I: https://doi.org/10.18485/philologia.2018.16.16.3

\title{
- L2 ACQUISITION AND PRODUCTION OF THE ENGLISH RHOTIC BY L1 GREEK-CYPRIOT SPEAKERS: THE EFFECT OF L1 ARTICULATORY ROUTINES AND PHONETIC CONTEXT
}

\author{
DIMITRA DIMITRIOU 1 \\ University of Central Lancashire
}

U ovoj studiji se ispituje produkcija engleskog rotičkog glasa kod govornika kiparskog grčkog, čija je tipična realizacija u L1 alveolarni dotačnik (eng. tap). Takođe se porede produkcija učenika koji pohađaju školu na engleskom i onih koji pohađaju školu na grčkom tokom srednjoškolskog obrazovanja. Ispitanici su studenti koji su bili uzrasta 17-21 kada su se preselili u Veliku Britaniju; dužina boravka bila je 1-4 godine, a starost ispitanika 18-24 godina. Kontrolnu grupu je sačinjavalo šestoro izvornih govornika engleskog. Učesnici su snimljeni dok izgovaraju liste reči na grčkom i engleskom jeziku sa rotičnim glasom na početnoj, međuvokalskoj poziciji i u grupama Cr i rC. Ispitivani su način tvorbe, trajanje i frekvencija formanata. Rezultati ukazuju na to da su učenici iz škola na engleskom jeziku uspešniji u produkciji engleskog aproksimanta nego polaznici škola na grčkom, premda nijedna od dve grupe ispitanika ne doseže vrednosti izvornih govornika u svim kontekstima, ni kada je reč o trajanju, ni kada je reč o frekvenciji formanata. Takođe su primećeni efekti fonetskog sistema L1 na produkciju rotičnog glasa u L2. Ova studija daje uvid u oblast kojoj je pruženo malo pažnje u kontekstu Kipra, kao i predstavlja osnov za buduće istraživanje koje može dovesti do poboljšanja u predavanju i učenju engleskog na Kipru i drugim jezicima sa sličnim fonetskim inventarom.

Ključne reči: L2 produkcija rotičkog glasa, SLM, asimilacija fonetske kategorije, disimilacija fonetske kategorije, interakcija L1-L2, grčko-kiparski učenici engleskog.

1 Contact information: dimitriou.dimitra18@gmail.com 


\section{INTRODUCTION}

Previous studies on the acquisition and production of the rhotic in a second language (L2) by groups of learners from various first-language (L1) backgrounds (e.g. Chan 2010; Rose 2010; Olsen 2012) demonstrate that rhotics are problematic in L2 speech acquisition, especially for learners whose $L 1$ and target L2 involve different realisations. However, to my knowledge, no previous study investigated the production of the rhotic approximant by native Greek or Greek-Cypriot learners of English, whose L1 involves a tap realisation of the rhotic. Therefore, the purpose of this study was to examine the acquisition of the rhotic approximant by native Greek-Cypriot learners of English, in order to identify the difficulties that these learners face in its production.

The task of the learner in acquiring the sound patterns of an $L 2$ in perception and production is complex and subject to various constraints. The question of how the two subsystems of a bilingual interact is addressed by Flege (1995) in his Speech Learning Model (SLM), according to which the L1 and L2 phonetic categories mutually influence one another through the processes of phonetic category assimilation and phonetic category dissimilation. Phonetic category assimilation occurs when the establishment of a new category is blocked due to the perception of an L2 sound as phonetically similar to an L1 sound, at least in the early stages of learning (Flege 1995). Phonetic category dissimilation occurs when a new phonetic category is ultimately formed for an L2 sound (Flege 1995). By hypothesis, whether a new category will be formed for an L2 sound depends on the degree of development of a neighbouring L1 sound, and the perceived phonetic dissimilarity of an L2 sound with the closest L1 sound (Flege 2007).

In addition, the SLM hypothesises that perception is linked to production in a way that difficulties in perception lead to difficulties in production, even though segmental production and perception are not necessarily brought into perfect alignment, as motor programs are also needed for successful production (Flege 2003). This means that learners may perceive the phonological characteristics of an L2 sound, but still have an inadequate knowledge of the motor commands required for its articulation (Leather and James 1991).

\section{THE RHOTIC IN STANDARD MODERN GREEK (SMG) AND CYPRIOT- GREEK (CYG) $)^{2}$}

The SMG rhotic is typically realised as an alveolar tap but can also occur as a short trill with two or three cycles (Arvaniti 1999a). Baltazani and Nicolaidis (2012; 2013) and Nicolaidis and Baltazani $(2011 ; 2014)$ examined the production of the rhotic in SMG, and found that it consists of two components: a single constriction and a vowellike transition (vocoid). The position of the vocoid was found to vary depending on its position; it appears between the constriction and the preceding or following consonant in $\mathrm{Cr}$ (Consonant-r) and rC (r-Consonant) clusters, and before the single constriction in

2 The terms "Greek-Cypriot" and "Cypriot-Greek" can be used interchangeably, although it is more common for the former to refer to people and the latter to refer to the dialect. 
phrase-initial position (Baltazani and Nicolaidis 2013). The duration of the rhotic was found to be on average 55-60 ms in consonant clusters (both components) (Baltazani 2009) and $23.3 \mathrm{~ms}$ in intervocalic position (only the constriction phase). In phrase-initial position, the constriction was found to be on average $24.7 \mathrm{~ms}$ long, while the vocoid was more than double in length $(50.43 \mathrm{~ms}$ ) in this position (Baltazani and Nicolaidis 2012).

The degree of constriction of the rhotic was found to vary from complete to incomplete contact and very open articulations. Overall, incomplete constrictions were found in $47 \%$ of the tokens in tautosyllabic Cr clusters, $57 \%$ in heterosyllabic $r C$ sequences, and 63\% in initial and intervocalic positions (Baltazani and Nicolaidis 2013). In addition, in rCand Crclusters, more tokens were produced with incomplete constriction in the context of a fricative compared to a stop (Fricative-r: $49 \%$ and r-Fricative: $67 \%$ compared to Stop-r: $44 \%$ and r-Stop 47\%). Finally, Baltazani (2005) briefly mentions the presence of frication noise in some tokens resulting from intermediate degrees of constriction. As regards the vocoid, the overwhelming majority of tokens (80\%) were produced with a modal or breathy voice, especially in $\mathrm{Cr}$ and phrase-initial contexts (Nicolaidis and Baltazani 2015).

Similarly to SMG, the rhotic in CyG is typically produced as a tap when single; however, Arvaniti (1999b; 2001a) and Arvaniti and Tserdanelis (2000) argue that the CyG system also contains a trill articulation of the rhotic when geminated. This is different from the realisations in SMG, which has no geminate productions. However, in the comparison between single segments in SMG and CyG, Arvaniti (2001b) found that the single $/ \mathrm{r} /$ was similar in duration in both varieties across speaking rates, which was expected since the tap is not free to shorten or lengthen at will. Overall, the realisation of the rhotic was found to be very similar in both varieties. Additionally, the lexical items used in this study are found in the vocabulary of both varieties and the Greek wordlist was written according to the SMG spelling and grammatical rules as CyG has no established orthography. Therefore, the results of this study may be at least to some extent generalised to SMG speakers as well.

\section{PRESENT STUDY}

This study focused on the production of the rhotic approximant by native GreekCypriot learners of English, in order to assess whether these learners face problems in its acquisition. In addition to investigating the acquisition of the rhotic approximant by learners whose L1 involves a tap, this study also compared two groups of GreekCypriot learners of English, namely learners that had attended English-speaking and learners that had attended Greek-speaking schools during their secondary education. More specifically, this study addressed the following research questions:

1. Does the phonetic system of the Greek-Cypriot dialect affect the production of the rhotic in English, and if so, in what ways?

a. In what contexts is the rhotic produced more accurately by GreekCypriots in terms of manner of articulation, and what are the possible reasons for that? 
b. How do Greek-Cypriot learners of English who study in the UK produce the rhotic approximant in different contexts, and how are their productions different from the productions of native English speakers in terms of duration and tongue configurations?

2. Is there a difference in the production of the rhotic between Greek-Cypriots that attended English-speaking private schools, and those that attended Greek-speaking public schools, and if so, why?

\section{METHODOLOGY AND PROCEDURES}

\subsection{SPEAKERS}

In order to address the research questions of this study, three groups of participants were required. Group A consisted of 13 Greek-Cypriot speakers who had attended public Greek-speaking schools in Cyprus during their primary and secondary education. The 9 participants in Group B had attended private English-speaking schools during their secondary education. All Greek-Cypriot participants had started learning English as a Foreign Language at an average age of 8 years. They had all obtained an IGCSE or IELTS certificate in order to be admitted to a UK university, and were therefore considered to be competent users of the English language. Participants in Groups A and B had arrived in the UK at an average age of 18.5 and had lived there for an average of 2.4 years. Their age ranged from 18-24 years old (average 20.6). The two CyG groups differed in their language use patterns during secondary school, as obtained through self-reports on a seven-point scale, but reported similar language use patterns during their university years. Table 1 presents the average values and range of values obtained by GreekCypriot participants regarding their language use patterns. Group ( was a control group and consisted of 6 monolingual native speakers of English (age range 19-22) who had been born, brought up and lived in Lancashire, UK at the time, chosen so as to avoid regional variation in the production of the rhotic. All participants were students at Lancaster University. More details concerning participants' characteristics can be found in Table $\mathrm{A} 1$ in the Appendix. 


\begin{tabular}{|c|c|c|c|c|c|}
\hline & \multicolumn{2}{|c|}{ Group A } & \multicolumn{2}{|c|}{ Group B } \\
\hline & & Average & Range & Average & Range \\
\hline \multirow{4}{*}{ L1 USE } & School: class & 6.85 & $6-7$ & 3.5 & $2-5$ \\
\hline & School: social & 6.92 & $6-7$ & 5.75 & $5-7$ \\
\hline & Uni: class & 2.23 & $1-5$ & 2.63 & $1-5$ \\
\hline & Uni: social & 5.08 & $4-6$ & 5.5 & $5-7$ \\
\hline \multirow{6}{*}{$\begin{array}{l}\text { L2 USE } \\
\text { (School) }\end{array}$} & Class & 2.31 & $1-3$ & 5.88 & $5-7$ \\
\hline & Social & 1.38 & $1-3$ & 2.75 & $1-5$ \\
\hline & Class (w. native) & 1.15 & $1-3$ & 3.75 & $1-6$ \\
\hline & Social (w. native) & 1.15 & $1-3$ & 3 & $1-5$ \\
\hline & Class (w. non-native) & 1.46 & $1-3$ & 2.5 & $1-7$ \\
\hline & $\begin{array}{c}\text { Social } \\
\text { (w. non-native) }\end{array}$ & 1.23 & $1-3$ & 2.13 & $1-7$ \\
\hline \multirow{6}{*}{$\begin{array}{c}\text { L2 USE } \\
\text { (University) }\end{array}$} & Class & 5.23 & $4-6$ & 5.63 & $5-7$ \\
\hline & Social & 4.15 & $3-6$ & 3.63 & $2-6$ \\
\hline & Class (w. native) & 4.15 & $1-7$ & 3.88 & $2-7$ \\
\hline & Social (w. native) & 3.08 & $1-5$ & 3.5 & $2-7$ \\
\hline & Class (w. non-native) & 3.69 & $1-7$ & 3.88 & $1-7$ \\
\hline & $\begin{array}{c}\text { Social } \\
\text { (w. non-native) }\end{array}$ & 3.62 & $1-6$ & 3.75 & $1-6$ \\
\hline \multirow[t]{2}{*}{ Motivation } & $\begin{array}{l}\text { Importance of } \\
\text { pronunciation }\end{array}$ & 5.85 & $3-7$ & 5.63 & $4-7$ \\
\hline & Attention paid & 4.77 & $3-7$ & 5.75 & $4-7$ \\
\hline
\end{tabular}

Table 1. Language use patterns of Greek-Cypriot participants based on self-reports

\subsection{SPEECH MATERIAL AND RECORDING SESSIONS}

Participants in Groups A and B were required to produce 16 Greek and 21 English tokens included in the carrier phrase" mu ipe ki efige" " he said and left") and interspersed with fillers. Group ( only read the English phrases. The tokens recorded contain a rhotic sound in six different contexts (Table 2). The same consonant clusters were used for both languages, apart from clusters that do not have an equivalent real Greek word. The same tautosyllabic vowel or variant was used for English tokens and 
their Greek equivalent ${ }^{3}$. Each phrase was presented separately using PowerPoint, and the process was repeated twice. Participant B8 was excluded from the study due to poor production caused by illness, rendering their productions inaudible. The total number of tokens analysed was 1134 English words ( 27 participants $\times 21$ tokens $\times 2$ repetitions) and 672 Greek words (21 participants $x 16$ tokens $x 2$ repetitions).

Recordings were carried out in comfortable and quiet environments at Lancaster University, individually or in groups of maximum 3 participants. The recorder used was a MicroTrack II 2-Channel Digital Recorder. The sessions lasted approximately 30 minutes for Greek-Cypriot speakers and 15 minutes for native English speakers.

\begin{tabular}{|c|c|c|}
\hline Context & English & Greek \\
\hline (1) Word-Initial & Rich & Rito ([ri'to] 'a saying') \\
\hline $\begin{array}{l}\text { (2) Word-Medial/ } \\
\text { Intervocalic }\end{array}$ & Very & Mesimeri ([mesi'meri] 'noon') \\
\hline \multirow{2}{*}{$\begin{array}{l}\text { (3a) Cr clusters with voiced } \\
\text { and } \\
\text { (3b) voiceless stops }\end{array}$} & $\begin{array}{l}\text { Brick } \\
\text { Drink } \\
\text { Grim }\end{array}$ & $\begin{array}{l}\text { Brizola ([bri'zole] 'steak') } \\
\text { Dripla (['driple] 'dribbling') } \\
\text { Grimatsa ([gri'metse] 'grimace') }\end{array}$ \\
\hline & $\begin{array}{l}\text { Priest } \\
\text { Tree } \\
\text { Cream }\end{array}$ & $\begin{array}{l}\text { Prin (['prin] 'before') } \\
\text { Triti (['triti] 'Tuesday) } \\
\text { Krima (['krime] 'shame') }\end{array}$ \\
\hline $\begin{array}{l}\text { (4) Cr clusters with voiceless } \\
\text { fricative }\end{array}$ & $\begin{array}{l}\text { Free } \\
\text { Three } \\
\text { Shrink }\end{array}$ & $\begin{array}{l}\text { Friki (['friki] 'horror') } \\
\text { Thrilos (['Orilos] 'legend') } \\
--\end{array}$ \\
\hline \multirow{2}{*}{$\begin{array}{l}\text { (5a) rC clusters with voiced } \\
\text { and } \\
\text { (5b) voiceless stops }\end{array}$} & $\begin{array}{l}\text { Orbit } \\
\text { Ordination } \\
\text { Organised }\end{array}$ & $\begin{array}{l}-- \\
-- \\
-- \\
\end{array}$ \\
\hline & $\begin{array}{l}\text { Harpoon } \\
\text { Artistic } \\
\text { Arcade }\end{array}$ & $\begin{array}{l}\text { Arpa (['erpe] 'harp') } \\
\text { Artios (['ertios] 'even (number)') } \\
\text { Arketa ([erke'te] 'enough') }\end{array}$ \\
\hline $\begin{array}{l}\text { (6) rC clusters with voiceless } \\
\text { fricatives }\end{array}$ & $\begin{array}{l}\text { Surfing } \\
\text { Earth } \\
\text { Arson } \\
\text { Harsh }\end{array}$ & 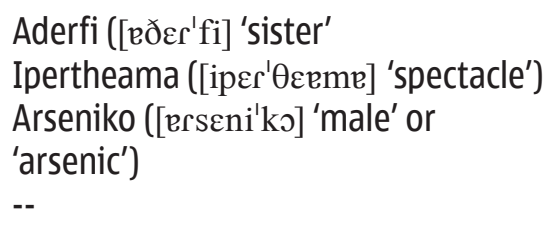 \\
\hline
\end{tabular}

Table 2. Tokens recorded in Greek and English, grouped according to the context of the rhotic

3 SMG and CyG have a 5-vowel system: /i, $\varepsilon, \mathrm{e}, \mathrm{o}$, u/. For a description of the quality of SMG vowels, see Arvaniti (1999a; 2007) and for CyG, Arvaniti (1999b). 


\subsection{MEASUREMENTS}

The analysis was carried out using Praat version 5.3.42. Rhotics were firstly classified according to their manner of articulation (approximant, tap, trill) based on auditory and acoustic analyses. One additional variant of the tap was discovered during analysis and was labelled as a tap followed by frication noise. Formant values at $50 \%$ were also taken. To measure its duration, the onset and offset of the rhotic were determined by changes on the spectrogram and/or waveform suggesting the onset or offset of the surrounding segments, combined with auditory analysis. The onset of word-initial taps and taps in Cr clusters was determined at the beginning of the vocoid. Care was taken to ensure that measurements were consistent across participants and tokens. An intra-rater reliability assessment of the measurements was carried out on a $10 \%$ representative sample of the data. The average absolute difference ranged from 2-8 ms and was considered acceptable; therefore, the original set of measurements was used for analysis.

Clusters with voiceless stops preceding the rhotic were excluded from duration and formant frequencies analyses due to the fact that as opposed to Greek /p, t, k/, English voiceless stops are produced with aspiration in syllable-initial position and this had different effects for Greek-Cypriot learners compared to native speakers. Duration and formant values for $\mathrm{rC}$ clusters are also not reported due to the lack of native speaker productions with which to make comparisons.

\subsection{HYPOTHESIS}

It was hypothesised that the highest proportion of approximants would be produced in Fricative-r and r-Fricative clusters in English by Greek-Cypriot speakers, followed by clusters with voiced and voiceless stops, and finally, by the rhotic in initial and intervocalic position. This hypothesis was based on the degree of constriction of the rhotic in various contexts in SMG, as examined by Baltazani and Nicolaidis (2013) (see section 2). In addition, even though in initial and intervocalic position the rhotic was found to be regularly produced with incomplete constriction in Baltazani and Nicolaidis (2013), Cruttenden and Gimson (2014: 227) argue that, "the approximant in initial position may be the most troublesome articulation of all" for foreign language learners. Therefore, I expected Greek-Cypriot learners to have some difficulty in producing the approximant in this position. Finally, where there is no equivalent CyG cluster, it was expected that the pronunciation would be more native-like. "Harsh" and "Shrink" were expected to be more accurately pronounced since the position of the tongue in $/ \delta /$ approximates more the position for the production of the English rhotic. 


\section{RESULTS}

\subsection{MANNER OF ARTICULATION}

One interesting result of the analysis was the production of the tap with frication noise in both Greek and English words, which has not been extensively discussed in the literature. These were instances where the constriction phase of the tap was followed by frication noise instead of the expected vocoid phase. Taps with frication noise only occurred in r-Fricative and r-(Voiceless)Stop clusters in Greek words and were the most common variant in these contexts by both Groups A and B. In English, the occurrence of this variant was reduced, especially for Group B; however, its occurrence in English was more widespread across contexts, with the most instances of this variant found in (Voiceless)Stop-r and r-(Voiceless)Stop clusters for both groups.

Tables 3 and 4 below show the percentage of occurrence of each variant in all contexts in English and Greek respectively as produced by Greek-Cypriot speakers. A quick overview reveals that both groups used more approximants in total than any other variant, with Group B producing more approximants than Group A overall. However, in combination with the taps with frication noise, the tap was used more often than approximants by participants in Group A making up for more than $53 \%$ of the productions for this group. Group B produced considerably more approximants than any other variant. This was also the case in rC clusters, where elision takes place for Group C. Group A on the other hand demonstrated greater variation. Interestingly, elision in $\mathrm{rC}$ clusters occurred slightly more often in the productions of Group A than Group B. However, approximant productions in these contexts were considered as accurate during the analysis, as elision is dependent on the variety of English used, despite the fact that the rhotic is omitted in the variety spoken by the control group in this study. 


\begin{tabular}{|c|c|c|c|c|c|c|c|c|c|c|}
\hline & \multicolumn{2}{|c|}{ Approximants } & \multicolumn{2}{|c|}{ Taps } & \multicolumn{2}{|c|}{ Taps (Frication) } & \multicolumn{2}{|c|}{$\emptyset$} & \multicolumn{2}{|c|}{ Trills } \\
\hline & $A$ & $B$ & $A$ & $B$ & $A$ & $B$ & $A$ & $B$ & $A$ & B \\
\hline Word Initial & $\begin{array}{c}10 / 26 \\
(38.46 \%)\end{array}$ & $\begin{array}{l}12 / 16 \\
(75 \%)\end{array}$ & $\begin{array}{c}16 / 26 \\
(61.54 \%)\end{array}$ & $\begin{array}{c}4 / 16 \\
(25 \%)\end{array}$ & - & - & - & - & - & - \\
\hline Intervocalic & $\begin{array}{c}5 / 26 \\
(19.23 \%)\end{array}$ & $\begin{array}{c}10 / 16 \\
(62.5 \%)\end{array}$ & $\begin{array}{c}21 / 26 \\
(80.77 \%)\end{array} \mid$ & $\begin{array}{c}6 / 16 \\
(37.5 \%)\end{array}$ & - & - & - & - & - & - \\
\hline Fricative-r & $\begin{array}{c}38 / 78 \\
(48.72 \%)\end{array}$ & \begin{tabular}{|c|}
$38 / 48$ \\
$(79.17 \%)$
\end{tabular} & $\begin{array}{c}35 / 78 \\
(44.87 \%)\end{array}$ & $\begin{array}{c}10 / 48 \\
(20.83 \%)\end{array}$ & $\begin{array}{c}4 / 78 \\
(5.13 \%)\end{array}$ & - & - & - & $\begin{array}{c}1 / 78 \\
(1.28 \%)\end{array}$ & - \\
\hline r-Fricative & $\begin{array}{c}52 / 104 \\
(50 \%)\end{array}$ & $\begin{array}{c}47 / 64 \\
(73.44 \%)\end{array}$ & $\begin{array}{c}19 / 104 \\
(18.27 \%)\end{array}$ & $\begin{array}{c}8 / 64 \\
(12.5 \%)\end{array}$ & $\begin{array}{c}14 / 104 \\
(13.46 \%)\end{array}$ & $\begin{array}{c}4 / 64 \\
(6.25 \%)\end{array}$ & $\begin{array}{c}19 / 104 \\
(18.27 \%)\end{array}$ & $\begin{array}{c}5 / 64 \\
(7.81 \%)\end{array}$ & - & - \\
\hline (Voiced)Stop-r & $\begin{array}{c}34 / 78 \\
(43.59 \%)\end{array}$ & $\begin{array}{l}36 / 48 \\
(75 \%)\end{array}$ & $\begin{array}{c}43 / 78 \\
(55.13 \%)\end{array}$ & $\begin{array}{l}12 / 48 \\
(25 \%)\end{array}$ & $\begin{array}{c}1 / 78 \\
(1.28 \%)\end{array}$ & - & - & - & - & - \\
\hline r-(Voiced)Stop & $\begin{array}{c}37 / 78 \\
(47.44 \%)\end{array}$ & \begin{tabular}{|c|}
$30 / 48$ \\
$(62.5 \%)$
\end{tabular} & $\begin{array}{c}24 / 78 \\
(30.77 \%)\end{array}$ & $\begin{array}{c}13 / 48 \\
(27.08 \%)\end{array}$ & $\begin{array}{c}10 / 78 \\
(12.82 \%)\end{array}$ & $\begin{array}{c}1 / 48 \\
(2.08 \%)\end{array}$ & $\begin{array}{c}7 / 78 \\
(8.97 \%)\end{array}$ & $\begin{array}{c}3 / 48 \\
(6.25 \%)\end{array}$ & - & $\begin{array}{c}1 / 48 \\
(2.08 \%)\end{array}$ \\
\hline $\begin{array}{c}\text { (Voiceless) } \\
\text { Stop-r }\end{array}$ & $\begin{array}{c}22 / 78 \\
(28.21 \%)\end{array}$ & \begin{tabular}{|c|}
$23 / 48$ \\
$(47.92 \%)$
\end{tabular} & $\begin{array}{c}23 / 78 \\
(29.49 \%)\end{array}$ & $\begin{array}{c}14 / 48 \\
(29.17 \%)\end{array}$ & $\begin{array}{c}\text { 33/78 } \\
(42.31 \%)\end{array}$ & $\begin{array}{c}11 / 48 \\
(22.92 \%)\end{array}$ & - & - & - & - \\
\hline $\begin{array}{c}\text { r-(Voiceless) } \\
\text { Stop }\end{array}$ & $\begin{array}{c}30 / 78 \\
(38.46 \%)\end{array}$ & $\begin{array}{c}23 / 48 \\
(47.92 \%)\end{array}$ & $\begin{array}{c}14 / 78 \\
(17.95 \%)\end{array}$ & $\begin{array}{c}9 / 48 \\
(18.75 \%)\end{array}$ & $\begin{array}{c}26 / 78 \\
(33.33 \%)\end{array}$ & $\begin{array}{c}9 / 48 \\
(18.75 \%)\end{array}$ & $\begin{array}{c}7 / 78 \\
(8.97 \%)\end{array}$ & $\begin{array}{c}7 / 48 \\
(14.58 \%)\end{array}$ & $\begin{array}{c}1 / 78 \\
(1.28 \%)\end{array}$ & - \\
\hline Total & $221 / 546$ & $219 / 336$ & $195 / 546$ & $76 / 336$ & $95 / 546$ & $25 / 336$ & $33 / 546$ & $15 / 336$ & $2 / 546$ & $1 / 336$ \\
\hline$\%$ & $40.48 \%$ & $65.18 \%$ & $35.71 \%$ & $22.62 \%$ & $17.4 \%$ & $7.44 \%$ & $6.04 \%$ & $4.46 \%$ & $0.37 \%$ & $0.3 \%$ \\
\hline
\end{tabular}

Table 3. Percentage of occurrence of each variant by Greek-Cypriot speakers in English tokens 


\begin{tabular}{|c|c|c|c|c|c|c|c|c|}
\hline & \multicolumn{2}{|c|}{ Taps } & \multicolumn{2}{|c|}{ Taps (Frication) } & \multicolumn{2}{|c|}{$\emptyset$} & \multicolumn{2}{|c|}{ Trills } \\
\hline & A & B & A & B & A & B & A & B \\
\hline Initial & $\begin{array}{c}24 / 26 \\
(92.31 \%)\end{array}$ & $\begin{array}{c}16 / 16 \\
(100 \%)\end{array}$ & - & - & - & - & $\begin{array}{c}2 / 26 \\
(7.69 \%)\end{array}$ & - \\
\hline Intervocalic & $\begin{array}{c}26 / 26 \\
(100 \%)\end{array}$ & $\begin{array}{c}16 / 16 \\
(100 \%)\end{array}$ & - & - & - & - & - & - \\
\hline Fricative-r & $\begin{array}{c}52 / 52 \\
(100 \%)\end{array}$ & $\begin{array}{c}32 / 32 \\
(100 \%)\end{array}$ & - & - & - & - & - & - \\
\hline r-Fricative & $\begin{array}{c}15 / 78 \\
(19.23 \%)\end{array}$ & $\begin{array}{c}22 / 48 \\
(45.83 \%)\end{array}$ & $\begin{array}{c}62 / 78 \\
(79.49 \%)\end{array}$ & $\begin{array}{c}25 / 48 \\
(52.08 \%)\end{array}$ & $\begin{array}{c}1 / 78 \\
(1.28 \%)\end{array}$ & - & - & $\begin{array}{c}1 / 48 \\
(2.08 \%)\end{array}$ \\
\hline (Voiced) Stop-r & $\begin{array}{c}78 / 78 \\
(100 \%)\end{array}$ & $\begin{array}{c}48 / 48 \\
(100 \%)\end{array}$ & - & - & - & - & - & - \\
\hline r-(Voiced) Stop & - & - & - & - & - & - & - & - \\
\hline (Voiceless)Stop-r & $\begin{array}{c}77 / 78 \\
(98.72 \%)\end{array}$ & $\begin{array}{c}48 / 48 \\
(100 \%)\end{array}$ & - & - & - & - & $\begin{array}{c}1 / 78 \\
(1.28 \%)\end{array}$ & - \\
\hline r-(Voiceless)Stop & $\begin{array}{c}25 / 78 \\
(32.05 \%)\end{array}$ & $\begin{array}{c}18 / 48 \\
(37.5 \%)\end{array}$ & $\begin{array}{c}50 / 78 \\
(64.10 \%)\end{array}$ & $\begin{array}{c}25 / 48 \\
(52.08 \%)\end{array}$ & - & - & $\begin{array}{c}3 / 78 \\
(3.85 \%)\end{array}$ & $\begin{array}{c}5 / 48 \\
(10.42 \%)\end{array}$ \\
\hline Total & $297 / 416$ & $200 / 256$ & $112 / 416$ & $50 / 256$ & $1 / 416$ & - & $6 / 416$ & $6 / 256$ \\
\hline$\%$ & $71.39 \%$ & $78.13 \%$ & $26.92 \%$ & $19.53 \%$ & $0.24 \%$ & - & $1.44 \%$ & $2.34 \%$ \\
\hline
\end{tabular}

Table 4. Percentage of occurrence of each variant by Greek-Cypriot speakers in Greek tokens

As regards the clusters not found in Greek phonology, "Shrink" was the most successful token in terms of manner of articulation for Group A, with the most instances of approximant productions compared to all other tokens across contexts (20/26). "Harsh" was also moderately successfully pronounced, having the most instances of elision in both Group A and B (11/26 and 4/16 respectively), compared to other tokens that native speakers produced with an omission of the /x/. Finally, r-(Voiced)Stop clusters were the second most accurately pronounced cluster for Group A, but fifth for Group B (combining both approximant productions and elision), indicating a higher success rate compared to other contexts for Group A. Approximants (plus elision where appropriate) for the two groups occur most often in the following order: 


\section{Group A}

1. r-Fricative (68.27\%)

2. r-(Voiced)Stop (56.41\%)

3. Fricative-r (48.72\%)

4. r-(Voiceless)Stop (47.43\%)

5. (Voiced)Stop-r (43.59\%)

6. Word-Initial (38.46\%)

7. (Voiceless)Stop-r (28.21\%)

8. Intervocalic (19.23\%)

\section{Group B}

1. r-Fricative (81.25\%)

2. Fricative-r (79.17\%)

3. (Voiced)Stop-r=Word-Initial (75\%)

4. r-(Voiced)Stop (68.75\%)

5. $r$-(Voiceless)Stop=Intervocalic (62.5\%)

6. (Voiceless)Stop-r (47.92\%)

\subsection{DURATION}

Unpaired t-tests were used to test statistical significance of the duration differences among groups in each context. In Fricative-r clusters, both Groups A and B had significant differences with Group C ( $p<0.0001$ for Group A and $p=0.012$ for Group B). Duration differences between Group A and Group B were also statistically significant in this case ( $p=0.01)$. Interestingly, in the individual token "Shrink", Group A had no significant differences compared to Group C $(p=0.196)$ whereas Group B did $(p=0.028)$. A significant difference was also found between the two Greek-Cypriot groups in this word ( $p=0.003$ ). In general, "Shrink" was more accurately produced by both Group A and Group B in terms of duration in comparison with "Free" and "Three" when the tokens were compared individually. In Stop-r clusters only Group A had significant duration differences ( $p=0.033$ ) with Group C. Groups A and B had no significant differences in these clusters. Group A's approximant duration was generally shorter than the other groups in both Fricative-r and Stop-r clusters. Finally, approximant duration in wordinitial and intervocalic positions was also examined, despite the limited number of approximants in these positions. All comparisons between the groups showed no statistical significance in their duration differences.

\subsection{FORMANT VALUES}

Formant values in both Fricative-r and Stop-r clusters follow a similar pattern, with the F1 slightly higher by Group C as opposed to Groups A and B, and F2 and F3 lower for this group. Again, Groups A and B shared similar ranges and averages, with a very slight tendency for Group B to produce lower F2 and F3 values than Group A. Unpaired t-tests were used to determine whether F1, F2 and F3 differences between the groups were significant in Fricative-r clusters. F1, F2 and F3 differences between Group A and Group $B$ were not statistically significant. Differences in F1, F2 and F3 between Group A and C and Group B and ( were found to be extremely statistically significant $(p<0.0001)$ in all comparisons. The same pattern was observed for Stop-r clusters, where Groups A and B 
had no significant differences whereas significant differences existed between Group A and $\mathrm{C}$ and Group B and C in F1, F2 and F3 ( $\mathrm{p}<0.0001$ in all comparisons).

Finally, in tokens with singleton $/ x /$, F1 differences among the groups were not statistically significant, whereas F2 differences between Group A and C and Group B and C were statistically significant in both "Rich" and "Very" ( $p=0.0004$ for Group A and C, $p=0.0016$ for B and C in "Rich"; $p=0.0002$ for Group A and C, $p<0.0001$ for Group B and C in "Very"), but not between Groups A and B. F3 differences were not significant among the three groups in "Rich", but they were in "Very", in which even Groups A and B had significant differences ( $p<0.0001$ for $A$ and $C, p=0.0002$ for $B$ and $C, p=0.025$ for $A$ and $B$ ).

\section{DISCUSSION}

\subsection{MANNER OF ARTICULATION}

The prediction that clusters with fricatives would favour approximant production in English by Greek-Cypriot speakers especially in rC clusters was confirmed for both groups. As mentioned in section 5.1 above, approximant productions in $\mathrm{rC}$ clusters were considered as accurate during the analysis of the results, despite the fact that the rhotic is omitted in the variety spoken by the control group in this study. The increased number of approximants found in clusters with fricatives was predicted based on Baltazani and Nicolaidis (2013), who found that in Greek rC and Cr clusters, more tokens were produced with incomplete constriction of the tap in the context of a fricative compared to a stop (see section 2). The next most successfully produced categories for Group A are r-Stop categories, with both voiced and voiceless stops (including both approximant productions and omissions). This was also expected as Baltazani and Nicolaidis (2013) found that $\mathrm{rC}$ sequences favour incomplete constrictions of the tap (57\% of their tokens produced with incomplete constriction of the tap, compared to $47 \%$ in (r clusters). As predicted, word initial and intervocalic contexts were among the least successful contexts, especially for Group A, along with (Voiceless)Stop-r clusters, which were found to cause difficulties to both groups, perhaps due to the aspiration of word-initial voiceless stops in English.

Group B produced a high percentage of approximants in word-initial position, contrary to the predictions, but not in intervocalic position, which is found at the bottom of the list. It is also important to note that for Group B, (Voiced)Stop-r is the only Cr context that is more successful than its $r($ equivalent, perhaps because $r$-(Voiced)Stop clusters are not found in SMG or CyG. In general, with the exception of (Voiceless)Stop-r clusters, the rhotic was produced as an approximant in more than $60 \%$ of the tokens in each context for this group, indicating a higher percentage of success compared to Group A. Overall, the results were contrary to the predictions for Group B, probably because this group had more overall experience in English. Their general success rate in all contexts was higher, indicating a process towards achieving complete overall success in the acquisition of the approximant, at least in terms of manner of articulation.

As regards the tokens labelled as taps with frication noise, Baltazani (2005) briefly mentions the occurrence of tokens produced with an intermediate degree of constriction 
resulting in frication. In addition, Nicolaidis and Baltazani (2015) observed that while in the majority of their tokens the vocoid phase of the rhotic was produced with a modal or breathy voice (see section 2), there was a large increase of vocoids with whispered quality in r( contexts (over $40 \%$ of the tokens in r( clusters), which was interpreted as an assimilatory effect to the following voiceless consonant. Therefore, the frication noise found in Greek rC clusters in this study can be interpreted as the vocoid phase of the tap produced with whispered quality, which extends to the production of the approximant in English rC clusters as well. Its frequency in (Voiceless)Stop-r clusters in English but not Greek tokens may be caused by the fact that in English, syllable-initial voiceless stops are aspirated, as opposed to syllable-initial voiceless stops in Greek. However, the effect of aspiration on rhotic production by English learners whose L1 has unaspirated syllable-initial voiceless stops needs to be further investigated.

Another interesting observation is that while Group B produced significantly more approximants than Group A in all contexts and overall, they did so in rC clusters as well, where the approximant is typically omitted in the productions of native speakers. Interestingly, Group A had a slightly higher percentage of elision in these contexts, especially in the individual token "Harsh". This phenomenon may be the result of input. Having more exposure to English from an earlier age, Group B may have been able to form a new category for the English approximant prior to their arrival in the UK; however, the input may not have been accurate enough to lead to the perception of elision, as teachers in Cyprus may have pronounced the rhotic in such contexts. On the other hand, category formation may not have been achieved by Group A prior to their arrival in the UK, where the native-speaker input may have led to a more British-like perception of elision in these contexts. At the same time, the effect of input by different varieties of English, such as American English may have influenced their representations, since Greek-Cypriot learners are more likely to have received more American-accented input prior to their arrival in the UK through American television programmes that are widely broadcast in Cyprus. In this case, even if both groups had the same amount of American-accented input, Group $B$ participants may have been more likely to form new categories prior to their arrival to the UK, due to the fact that they had more exposure to English earlier in life than Group A participants. Orthographic effects may also affect Greek-Cypriots in general in these clusters, since Greek is a language with a letter-sound correspondence. Further research focusing on the investigation of this observation could provide more insights explaining the effect of input on category formation for this group of learners.

\subsection{DURATION}

With regard to duration, whereas neither Group A nor Group B achieved overall native-like duration of the approximant, Group $B$ produced longer durations than Group A, approximating more the native productions. Groups A and B only differed significantly in Fricative-r clusters, which suggests that Group B may have achieved a slight modification of the duration values in these clusters. However, the significant differences between Group B and Group C in these clusters indicate that nativelike duration was still not achieved by these learners. Group B did, however, achieve native-like approximant duration in Stop-r clusters, where there were no significant 
differences compared to Group C. Group A on the other hand was not so successful, since there were significant duration differences in both Fricative-r and Stop-r clusters compared to Group C.

In word-initial and intervocalic positions, neither Groups A nor B had significant differences compared to Group C. The limited number of approximant productions in these contexts suggests that these learners, especially Group A, face difficulties in producing the approximant in these positions, but as soon as they overcome manner of articulation difficulties, they are relatively successful in terms of duration. The generally shorter durations of the two Greek-Cypriot groups, and especially of Group A, may be the result of an effect of the L1 phonetic system on the L2 rhotic acquisition, as the L1 tap is shorter in duration, possibly affecting the realisation of the $L 2$ approximant when it occurs.

\subsection{FORMANT VALUES}

Formant values in Fricative-r and Stop-r clusters indicate that Greek-Cypriot speakers produce $/ x /$ with a higher and more fronted tongue position, and with less lip rounding than native English speakers. Whether Greek-Cypriots' productions were affected to a greater degree than native speakers' productions by the vowel in the environment of the rhotic (a variant of / $\mathrm{i} /$ in the majority of the tokens) needs to be further explored in future research, since different neighbouring vowels may exert a different influence on the production of the approximant by learners of English.

Overall, formant values indicate that tongue height was more similar between Groups A and B and Group C in Initial and Intervocalic positions than in Fricative- $r$ and Stop-r clusters, but the approximant was still produced as more fronted and with less lip rounding in both words. More native-like productions seem to be achieved in word-initial position followed by intervocalic position, again providing support for the hypothesis that as long as the approximant is acquired, it is produced more accurately in Initial and Intervocalic position than in Cr clusters. However, the data collected for these contexts, as well as the limited number of approximant productions by the GreekCypriot participants in these contexts do not allow for any claims to be made with confidence.

\subsection{L1-L2 INTERACTION - L1 EFFECTS}

Greek-Cypriot speakers were less successful in / $\mathrm{x} /$ production than the Cantonese ESL learners in Chan (2010) (46.52\% of approximants plus elision for Group A and 69.64\% for Group B, compared with 87.5\% for Cantonese learners in Chan 2010). Similarly to Cantonese learners in this study, and contrary to the SLM hypothesis, the absence of an approximant in the CyG and SMG phonological system does not seem to facilitate its acquisition and production in the L2. Olsen (2012) reports the same phenomenon for L1 English learners of Spanish, who produce the Spanish rhotic as an approximant instead of a tap. This is the result of the L2 category being affected "by the phonological 
structure of those L1 categories to which they are most similar, at least in the early stages of L2 development" (Olsen 2012: 70). In the case of Greek-Cypriot learners, and based on the assumptions of the SLM, approximants may at the first stages of learning be perceived as the CyG tap, blocking the establishment of a new category, due to a small but sufficient perceived phonetic similarity between them.

However, there is no reason to assume that the CyG tap and the English approximant are perceived to be the same sound, at least after the initial stages of learning, as the two sounds are inherently different. In theory, based on the fact that taps and approximants are very different, and the phonetic inventory of (Cypriot-)Greek does not contain an approximant rhotic, native (Cypriot-)Greek learners should be able to form a new category for the English rhotic (see section 1). However, this does not mean that they will produce the approximant instead of the tap in their speech, neither that they will do so accurately, due to articulatory difficulties, or due to the added effort of producing an approximant instead of the well-known articulatory configurations for a tap (Leather and James 1991; Flege 2003). When the approximant is used, its production is different than the native productions in terms of duration and tongue position, providing support for the argument that while learners may perceive the phonological characteristics of an L2 sound, they may still face motor constraints in its articulation. Seeing that the participants in Group B, who had more experience in English and had used it more often in earlier stages compared to Group A participants, produced higher rhotic accuracy rates, there is no reason to assume that Group A participants will not eventually achieve the same accuracy.

The success in the production of clusters that have no Greek equivalent (i.e. $\mathrm{Cr}$ and $\mathrm{rC}$ clusters with / $/$ / and $\mathrm{rC}$ (clusters with voiced stops) especially by Group A, points to an explanation of new category formation. Based on the assumptions of the SLM, since no Greek equivalent exists to cause transfer, a new category is more likely to be formed for the rhotic in these clusters, which will reflect the native input that the learners had experienced. In addition, the consonantal environment of the rhotic in these tokens favoured approximant production due to the similarity in place of articulation between $\mid S /$ and $/ \mathrm{x} /$. At the same time, their apparently limited success may be due to the learners having received inadequate amounts of input due to their L1-L2 use patterns during their stay in the UK. With regard to r-(Voiced)Stop clusters, although they seem to be moderately successful in terms of manner of articulation especially for Group A, the extensive use of taps and taps with frication noise (43.59\% for Group A and $29.16 \%$ for Group B) calls for further investigation of the success rate in this context.

\section{CONCLUSION}

This study investigated rhotic production by native Greek-Cypriot speakers who had started learning English as an L2 at an early age but had arrived in a predominantly English-speaking country late in life, in early adulthood. The research questions investigated were the following:

1. Does the phonetic system of the Greek-Cypriot dialect affect the production of the rhotic in English, and if so, in what ways? 
a. In what contexts is the rhotic produced more accurately by GreekCypriots in terms of manner of articulation, and what are the possible reasons for that?

b. How do Greek-Cypriot learners of English who study in the UK produce the rhotic approximant in different contexts, and how are their productions different from the productions of native English speakers in terms of duration and tongue configurations?

2. Is there a difference in the production of the rhotic between Greek-Cypriots that attended English-speaking private schools, and those that attended Greek-speaking public schools, and if so, why?

To summarise the findings concerning research question $1 \mathrm{a}$, differences were found between the two Greek-Cypriot groups as to the contexts in which the approximant was more accurately produced, with a general tendency for clusters with fricatives to favour approximant production. Word-initial / $/ \mathrm{I} / \mathrm{had}$ a different success rate for the two Greek-Cypriot groups, whereas intervocalic/./ was the least successful for Group A and second to last for Group B. Clusters with voiceless stops before the rhotic were among the least successful by both groups as a possible result of the aspiration differences in syllable-initial voiceless stops between the two languages, and were therefore excluded from duration and formant frequencies analyses. The relative success of some but not other contexts was attributed to the degree of constriction of the tap in the equivalent contexts in CyG and SMG on the one hand, and to ease of articulation on the other.

With regard to research question 1b, neither Group A nor Group B achieved overall native-like duration of the approximant in all contexts. Group B showed a tendency to approximate native-like durations especially in (Voiced)Stop-r clusters. Group A had significant differences compared to the native speakers in both Fricative-r and (Voiced)Stop-r clusters. It was also found that in word-initial, intervocalic and partially in (Voiced)Stop-r positions, Greek-Cypriot speakers are more successful in achieving native-like duration, but only after they overcome manner of articulation difficulties, as opposed to clusters with fricatives in which approximants are generally more frequent but native-like duration is not achieved. In terms of formant frequencies, Greek-Cypriots showed a possible influence of the tautosyllabic vowel on rhotic production, with their approximants produced higher, more fronted and with less lip rounding than those of the native speakers. Again, "Rich" and "Very" seem to be more successful than Fricative-r and Stop-r clusters in terms of tongue configuration, providing support for the hypothesis that as long as the approximant is acquired in these contexts, more accurate duration and formant values are achieved.

Concerning research question 2, apart from the differences already discussed, students that attended English-speaking schools (Group B) appear to perceive and produce the English approximant more accurately than the students that attended Greek-speaking schools (Group A). In general, Group B produces considerably more approximants than taps in all contexts and more than Group A. However, whereas students from an English-speaking school background are more successful in terms of the duration and tongue configurations for the approximant, both groups have yet to 
acquire the specific phonetic features of the English approximant as produced by native speakers of English. Group B's relative success compared to Group A was attributed to their higher degree of exposure to English as well as more native-speaker input during the early stages of learning, which may have resulted in new category formation prior to their arrival in the UK, as opposed to Group A, whose experience and native-speaker input in the early stages of learning was much less. This, however, appears to have implications in words that have no equivalent clusters in Greek, where Group A shows a slightly higher percentage of success compared to Group B, probably resulting from having received more accurate British English input. Speakers in both groups have begun learning English at approximately the same age, for a similar number of years, and with similar age of arrival and length of residence in the British-English-speaking community. Therefore, the difference in the degree of success between the two groups can be attributed to the differences in the quantity and quality of input received during the early stages of learning.

One implication of this study is that it proves the importance of the instruction of L2 pronunciation in early stages, especially when it takes place in a non-L2-speaking country. Greek-speaking schools could benefit from some routines used by Englishspeaking schools. For example, they could have at least some teachers of English that are native speakers of the language, or that have been assessed and found to have a near-native competence not only in knowledge of the grammatical structures, but in pronunciation accuracy as well. Importantly, this study was exploratory in nature, aiming to provide some preliminary observations on the English rhotic acquisition by native speakers of CyG in several contexts, and to offer possible lines per future investigations. Future research with specific focus on one or more contexts and with more tokens per context is required to provide a more complete picture of the production of the approximant by Greek or Greek-Cypriot learners of English.

Finally, the findings of this study should be interpreted with caution due to some methodological limitations. Firstly, language use patterns were obtained through self-reports, which is the most widely used but not necessarily reliable measure. In addition, the data were recorded in a controlled and not spontaneous environment, which makes speakers more conscious of their speech, resulting in better productions than might have been achieved in normal speech. However, structured elicitation was necessary in this study, to control for the contexts and vocalic or consonantal environments of the rhotic. Finally, the unequal number of speakers in each group, and of males and females within and across groups was not ideal, but unfortunately this was unavoidable due to the specific criteria needed to be fulfilled for participation, especially since students from Greek-speaking schools significantly outnumber students from English-speaking schools.

\section{ACKNOWLEDGEMENTS}

Firstly, I would like to thank the 28 Lancaster University students that provided the data in this study. I would also like to thank my MA supervisor Sam Kirkham for his valuable guidance and support, without which this study would not have been possible. 


\section{REFERENCES}

Arvaniti, A. 1999a. Standard Modern Greek. Journal of the International Phonetic Association 29, 167-172.

Arvaniti, A. 1999b. Cypriot Greek. Journal of the International Phonetic Association 29, 173-178.

Arvaniti, A. 2001a. Cypriot Greek and the phonetics and phonology of geminates. Modern Greek Dialects and Linguistics Theory 1, 19-30.

Arvaniti, A. 2001b. Comparing the Phonetics of single and geminate consonants in Cypriot and Standard Greek. $4^{\text {th }}$ International Conference on Greek Linguistics, Thessaloniki, 37-44.

Arvaniti, A. 2007. Greek phonetics: The state of the art. Journal of Greek Linguistics 8, 97-208.

Arvaniti, A. and G. Tserdanelis. 2000. On the phonetics of geminates: Evidence from Cypriot Greek. Proceedings of the $6^{\text {th }}$ International Conference on Spoken Language Processing, Beijing, China, 559-562.

Baltazani, M. 2005. Phonetic variability of the Greek rhotic sound. Phonetics and Phonology in Iberia 5.

Baltazani, M. 2009. Acoustic characterization of the Greek rhotic in clusters. Proceedings of the $18^{\text {th }}$ International Symposium of Theoretical and Applied Linguistics, Thessaloniki, Greece, 87-95.

Baltazani, M. and K. Nicolaides. 2013. The many faces of /r/. In L. Speafico and A. Vietti (eds.) Rhotics. New data and perspectives. Bosen Bolsano: Bu Press, 125-144.

Baltazani, M. and K. Nicolaidis. 2012. Production of the Greek rhotic in initial and intervocalic position: An acoustic and electropalatographic study. Selected papers of the $10^{\text {th }}$ International Conference on Greek Linguistics, 141-152.

Chan, A. Y. W. 2010. Advanced Cantonese ESL learners' production of English speech sounds: Problems and strategies. System 38, 316-328.

Cruttenden, A. and A. C. Gimson. 2014. Gimson's pronunciation of English. $8^{\text {th }}$ edition. Abingdon: Routledge.

Flege, J.E. 1995. Second language speech learning: Theory, findings, and problems. In W. Strange (ed.) Speech perception and linguistic experience: Issues in cross-language research. Timonium, MD: York Press, 233-277.

Flege, J. E. 2003. Assessing constraints on second-language segmental production and perception. In A. Meyer and N. Schiller (eds.) Phonetics and phonology in language comprehension and production, differences and similarities. Berlin: Mouton de Gruyter, 319-355.

Flege, J. E. 2007. Language contact in bilingualism: Phonetic system interactions. In J. Cole and J. I. Hualde (eds.) Laboratory Phonology 9, Berlin: Mouton de Gruyter, 353-381.

Leather, J. and A. James. 1991. The acquisition of second language speech. Studies in Second Language Acquisition 13, 305-341.

Nicolaidis, K. and M. Baltazani, 2014. The Greek rhotic in/rC/ sequences: An acoustic and electropalatographic study. In N. Lavidas, T. Alexiou and A. M. Sougari (eds.) Major trends in theoretical and applied linguistics. Volume 1. De Gruyter, 157-176. 
Nicolaidis, K. and M. Baltazani, 2015. An investigation of acoustic and articulatory variability during rhotic production in Greek. Proceedings of the $11^{\text {th }}$ International Conference on Greek Linguistics, Rhodes, Greece.

Nicolaidis, K. and M. Baltazani. 2011. An electropalatographic and acoustic study of the Greek rhotic in $/ \mathrm{Cr} /$ clusters. Proceedings of the $17^{\text {th }}$ International Congress of Phonetic Sciences, 1474-1478.

Olsen, M. K. 2012. The L2 acquisition of Spanish rhotics by L1 English speakers: The effect of L1 articulatory routines and phonetic context for allophonic variation. Hispania $95,65-82$.

Rose, M. 2010. Intervocalic tap and trill production in the acquisition of Spanish as a Second Language. Studies in Hispanic and Lusophone Linguistics 3, 379-420.

\section{SUMMARY}

\section{L2 ACQUISITION AND PRODUCTION OF THE ENGLISH RHOTIC BY L1 GREEK-CYPRIOT SPEAKERS: THE EFFECT OF L1 ARTICULATORY ROUTINES AND PHONETIC CONTEXT}

This study investigates the production of the English rhotic by Greek-Cypriot speakers, whose L1 typically involves a tap realisation. It also compares the productions of Greek-Cypriot learners that attended English-speaking schools with the productions of students that attended Greek-speaking schools during their secondary education. Participants were university students whose age of arrival in the UK was 17-21 years old, length of residence 1-4 years and age range 18-24 years. Six native speakers of English comprised the control group. Participants were recorded producing a Greek and an English wordlist with the rhotic in word-initial and intervocalic position, and in $\mathrm{Cr}$ and $\mathrm{rC}$ clusters. Manner of articulation, duration and formant frequencies were investigated. The results suggest that learners from English-speaking schools are more successful in the production of the English approximant than learners from Greekspeaking schools, although neither group reaches native-like values in all contexts in either duration or formant frequencies. Effects of the L1 phonetic system on L2 rhotic production are also found. This study provides insights on a subject that has received limited attention in the context of Cyprus, as well as a basis for future research that may lead to improvements in English language learning and teaching in Cyprus and other countries with similar phonetic inventories.

KEYWORDS: L2 rhotic production, SLM, phonetic category assimilation, phonetic category dissimilation, L1-L2 interaction, Greek-Cypriot learners of English. 


\section{APPENDIX}

Table A1. Participant characteristics

\begin{tabular}{|c|c|c|c|c|c|c|c|}
\hline Participant & Gender & YoS & Degree & Age & AOA & LOR & AOL \\
\hline A1 & Female & 1 & BSc Biomedical Sciences & 19 & 18 & 1 & 9 \\
\hline $\mathrm{A} 2$ & Male & 4 & MSc Data Science & 23 & 20 & 4 & 8 \\
\hline A3 & Male & 4 & MSc Biomedical Sciences & 24 & 20 & 4 & 8 \\
\hline A4 & Female & 3 & BSc Mathematics & 21 & 18 & 3 & 9 \\
\hline A5 & Female & 3 & BSc Mathematics & 21 & 18 & 3 & 8 \\
\hline A6 & Female & 3 & BSc Psychology & 20 & 18 & 3 & 8 \\
\hline A7 & Female & 3 & MSc Biological Sciences & 21 & 18 & 3 & 9 \\
\hline A8 & Female & 3 & BSc Biomedicine & 20 & 18 & 3 & 7 \\
\hline A9 & Female & 3 & BSc Economics & 20 & 18 & 3 & 8 \\
\hline A10 & Male & 1 & BEng Engineering & 21 & 20 & 1 & 8 \\
\hline A11 & Female & 3 & BSC Accounting and Finance & 20 & 17 & 3 & 8 \\
\hline A12 & Female & 3 & BSC Accounting and Finance & 20 & 17 & 3 & 9 \\
\hline A13 & Female & 3 & BSC Accounting and Finance & 21 & 18 & 3 & 8 \\
\hline B1 & Female & 1 & BSc Biomedical Sciences & 18 & 17 & 1 & 7 \\
\hline B2 & Female & 1 & BSc Biomedical Sciences & 20 & 19 & 1 & 8 \\
\hline B3 & Female & 2 & BSc Mathematics with Statistics & 20 & 18 & 2 & 8 \\
\hline B4 & Female & 2 & BSC Accounting and Management & 20 & 19 & 2 & 9 \\
\hline B5 & Female & 2 & BSc Mathematics & 20 & 19 & 2 & 8 \\
\hline B6 & Male & 1 & BSc Economics & 21 & 21 & 1 & 10 \\
\hline B7 & Male & 1 & BSc Accounting and Finance & 20 & 19 & 1 & 10 \\
\hline B8 & Female & 3 & BSC Accounting and Finance & 21 & 18 & 3 & 8 \\
\hline B9 & Female & 3 & Mathematics and Statistics & 22 & 19 & 3 & 8 \\
\hline $\mathrm{C} 1$ & Male & 2 & BSc Business Economics & 19 & & & \\
\hline $\mathrm{C2}$ & Female & 3 & BA Ethics, Philosophy and Religion & 21 & & & \\
\hline C3 & Mal & 4 & $\begin{array}{l}\text { MA English Language and } \\
\text { Literary Studies }\end{array}$ & 22 & & & \\
\hline C4 & Male & 3 & BA English Language & 20 & & & \\
\hline C5 & Male & 2 & BSc Physics & 19 & & & \\
\hline C6 & Male & 2 & $\begin{array}{l}\text { BA English Literature and } \\
\text { Philosophy }\end{array}$ & 20 & & & \\
\hline
\end{tabular}

Note: YoS: Year of Studies, AOA: Age of arrival in the UK, LOR: Length of residence in the UK, AOL: Age of learning of English as a foreign language in school.

ARTICLE INFO:

Original research article

Received: June 14, 2018

Revised: February 2, 2019

Accepted: February 13, 2019 